\title{
Pengaruh Citra Merek dan Kualitas Produk terhadap Keputusan Pembelian Smartphone Iphone Pada Mahasiswa di Universitas Mataram
}

\author{
Baiq Lani Septia Lestari ${ }^{*}$, Emilia Septiani ${ }^{1}$ \\ ${ }^{1}$ Program Studi Manajemen, Fakultas Ekonomi dan Bisnis, Universitas Mataram, Indonesia. \\ ${ }^{2}$ Pascasarjana, Universitas Mataram, Mataram, Indonesia \\ Corresponding Author Email: baiqlani@gmail.com
}

Received: March 9th, 2021

Article Info

Revised: 23 April 2021

Accepted: 30 April 2021

\begin{abstract}
This study aims to analyze the effect of brand image and product quality on iPhone smartphone purchasing decisions among students at the University of Mataram. This type of research used in this research is associative with a quantitative approach. The sampling technique was determined by purposive sampling method with a total of 100 respondents. The data collection tools used a questionnaire and google form which had been tested for validity and reliability. The data analysis technique used is multiple linear regression. The results of this study indicate that: (1) There is a positive and significant influence of brand image variables on purchasing decisions, (2) There is a positive and significant influence on product quality variables on iPhone smartphone purchasing decisions among students at the University of Mataram.
\end{abstract}

Keywords: Brand Image; Product Quality; Purchase Decision

Abstrak: Penelitian ini bertujuan untuk menganalisis pengaruh citra merek dan kualitas produk terhadap keputusan pembelian smartphone iPhone pada mahasiswa di Universitas Mataram. Jenis penelitian yang digunakan dalam penelitian ini adalah asosiatif dengan pendekatan kuantitatif. Tehnik pengambilan sampel ditentukan dengan metode purposive sampling dengan jumlah responden sebanyak 100. Alat pengumpulan data menggunakan kuesioner dan google form yang telah di uji validitas dan reliabilitasnya. Teknik analisis data yang digunakan adalah regresi linier berganda.Hasil penelitian ini menunjukkan bahwa: (1) Terdapat pengaruh positif dan signifikan variabel citra merek terhadap keputusan pembelian; (2) Terdapat pengaruh positif dan signifikan variabel kualitas produk terhadap keputusan pembelian smartphone iPhone pada mahasiswa di Universitas Mataram.

Kata Kunci: Citra Merek; Kualitas Produk; Keputusan Pembelian

Sitasi: Lestari, B., \& Septiani, E. (2021). Pengaruh Citra Merek dan Kualitas Produk terhadap Keputusan Pembelian Smartphone Iphone Pada Mahasiswa di Universitas Mataram. ALEXANDRIA (Journal of Economics, Business, E Entrepreneurship), 2(1). 11-18. doi:https://doi.org/10.29303/alexandria.v2i1.26

\section{Pendahuluan}

Kemajuan teknologi saat ini sangat berkembang pesat dan membantu manusia untuk berinteraksi satu sama lain tanpa dibatasi oleh jarak dan waktu (Daeng et al., 2017). Kemudahan yang diberikan oleh teknologi tersebut mencakup banyak hal serta merambah berbagai aspek, mulai dari bisnis hingga pendidikan. Pada prinsipnya teknologi berkembang untuk memenuhi kebutuhan dan keinginan manusia agar dalam kehidupannya dapat lebih mudah berkomunikasi ataupun melakukan sesuatu, maka sarana komunikasi sesuatu yang sangat penting dibutuhkan dalam kehidupan masyarakat (Amalia et al., 2018).

Pada umumnya masyarakat membeli smartphone untuk membantu serta mempermudah aktivitas seharihari dan juga untuk mendapatkan suatu prestise yang akan memberikan kepuasan tersendiri bagi si pemilik. Semakin tinggi minat konsumen terhadap produk smartphone, maka produsen/vendor smartphone 
berlomba-lomba memproduksi lini produk yang dapat memenuhi kebutuhan konsumen dan menarik konsumen untuk membeliproduknya.

Seiring dengan perkembangan zaman yang terus berubah, gaya hidup konsumen pun juga mulai berubah (Hartati et al., 2017). Untuk memilih produk, konsumen dengan gaya hidup yang cukup tinggi, biasanya akan memilih merek apa yang sedang populer saat ini. Hal ini disebabkan oleh adanya tuntutan gaya hidup yang semakin mendorong konsumen untuk selalu terlihat tampil up to date. Perusahaan harus memiliki keunggulan kompetitif yang sangat bergantung pada kemampuan perusahaan untuk memberikan nilai yang lebih tinggi dari para pesaingnya (Kasmawati, 2018). Oleh karena itu, perusahaan harus memahami kebutuhan dan minat konsumen agar konsumen dapat memutuskan untuk membeli produk atau jasa yang disediakan.

Salah satu pelopor perkembangan teknologi di bidang komunikasi yang sudah memiliki citra merk yang tinggi dan kualitas produknya sudah terpercaya diseluruh dunia adalah Apple dengan smartphone berbasis IOS yang mereka beri nama iPhone. iPhone adalah salah satu produk yang memproduksikan dari Apple yang sangat menggemparkan dunia saat pertama kali diperkenalkan pada tahun 2007. Sejarah iPhone dimulai saat Steve Jobs, CEO dari Apple inc memerintahkan para ilmuwan dari Apple mempelajari secara lebih mendalam teknologi layar sentuh.

Pengembangan dari unit iPhone itu sendiri dimulai nyaris 10 tahun sebelum Apple pertama diluncurkan di pasaran. Pada tahun 1999, Apple mematenkan hak untuk menggunakan domain iPhone. Apple mengumumkan rencana mereka untuk berinvestasi di bidang telepon genggam yang diberikan nama iPhone. iPhone sendiri adalah smartphone buatan Apple yang menggunakan sistem operasi iOS pada perangkatnya, iOS adalah sistem operasi perangkat bergerak yang dikembangkan dan didistribusikan oleh perusahaan Apple Inc. Sistem operasi iOS pertama kali diluncurkan pada tahun 2007 untuk digunakan pada produk iPhone dan iPod Touch. Citra merek iPhone di kalangan Global merupakan produk nomor 1, pengguna iPhone dapat mengenali dan mengoperasionalkan produk iPhone dengan mudah karena iPhone di rancang untuk kemudahan mobilitas dan bentuk fisik yang khas. iPhone dirancang dengan sistem operasi yang berbeda dengan smartphone lain, dan hanya produk dari Apple yang menggunakan os sendiri, ini menjadi nilai plus tersendiri untuk perangkat Apple. Berikut adalah Top Brand Award 5 Merek Smartphone di Indonesia tahun 2020.
Tabel 1. Top Brand Index 5 merek Smartphone di Indonesia tahun 2020

\begin{tabular}{lll}
\hline NO & MEREK & TBI 2020 \\
\hline 1. & SAMSUNG & $46,0 \%$ \\
2. & OPPO & $15,1 \%$ \\
3. & XIAOMI & $11,6 \%$ \\
4. & iPHONE & $9,1 \%$ \\
5. & VIVO & $7,9 \%$ \\
\hline
\end{tabular}

Sumber: $\underline{\text { www.topbrand-award.com }}$

Dari Tabel 1 memperlihatkan perkembangan pangsa pasar iPhone terjadi penurunan top brand 2020 hal ini dikarenakan penurunan penjualan iPhone tidak muncul dengan tiba-tiba, namun ada beberapa alasan turunnya penjualan iPhone dikarenakan banyaknya pesaing yang menawarkan harga yang lebih murah dan munculnya merek-merek smartphone android terbaru yang menyebabkan penjualan smartphone iPhone menurun, selain itu juga dikarenakan adanya wabah virus corona atau covid-19 yang mengakibatkan turunnya perekonomian dunia yang menjadi salah satu faktor penurunan penjualan iPhone.

Perusahaan yang cerdas akan mencoba memahami sepenuhnya proses pengambilan keputusan pelanggan, semua pengalaman mereka dalam belajar, memilih, menggunakan, bahkan dalam mendisposisikan produk. Proses pengambilan keputusan untuk membeli suatu produk dimulai dari pengenalan masalah, pencarian informasi, evaluasi terhadap beberapa alternatif, yang selanjutnya akan tercipta suatu keputusan pembelian serta terbentuknya perilaku paska pembelian (Maharani, 2015).

Keputusan pembelian merupakan pemikiran dimana individu mengevaluasi berbagai pilihan dan memutuskan pilihan pada suatu produk dari sekian banyak pilihan. Menurut Kotler \& Armstrong, (2012), keputusan pembelian adalah tahap dalam proses pengambilan keputusan pembeli di mana konsumen benar-benar membeli. Suatu produk biasanya diikuti serangkaian atribut dalam memilih produk, yaitu dari citra merek dan kualitas produk (Kotler \& Armstrong, 2012). Citra merek dan kualitas produk tentunya penting bagi para konsumen untuk membantu mereka memilih suatu produk yang sesuai keinginan konsumen dalam pengambilan keputusan pembelian ponsel.

Citra merek atau brand image adalah representasi dari keseluruhan persepsi terhadap merek yang dibentuk dari informasi dan pengalaman masa lalu terhadap merek itu. Citra terhadap merek berhubungan dengan sikap yang berupa keyakinan dan preferensi terhadap suatu merek (Permana et al., 2014). Citra merek dari iPhone ini sudah menguasai hampir seluruh penjuru dunia, sehingga para user atau mahasiswa yang menggunakan iPhone akan merasa bangga dan percaya diri saat menggunakan iPhone di depan umum 
karena citra merk yang dibangun oleh iPhone menunjukan kualitas produk yang sangat bagus dan harga yang sangatmahal.

Kualitas produk (product quality) merupakan senjata strategi potensial untuk mengalahkan pesaing (Oktavenia \& Ardani, 2018). Kemampuan dari kualitas produk untuk menunjukkan berbagai fungsi termasuk di dalamnya ketahanan, handal, ketepatan, dan kemudahan dalam penggunaan (Kotler \& Arstrong dalam Dewi et al., 2015). Kualitas produk dari iPhone ini terus berinovasi dalam memproduksi produkproduk smartphone yang berkualitas dan canggih yang dapat memenuhi kebutuhan masyarakat moderen saat ini. iPhone memproduksi produk baru dengan spesifikasi dan fitur-fitur lebih lengkap dan menarik konsumen sehingaa kini bnyak diminati oleh masyarakat Indonesia baik dari kalangan ekonomi menengah sampai ekonomi atas karena iPhone produk yang harganya cukup mahal, murah atau mahalnya harga tergantung pada spesifikasi, keunggulan dan kualitas dari produk itu sendiri. Penelitian ini mengambil objek pada Universitas Mataram.

Universitas Mataram merupakan perguruan tinggi yang terletak di Jl. Majapahit No. 62, Gomong, Kec. Selaparang, Kota Mataram, Nusa Tenggara Barat. Universitas Mataram memiliki 9 fakultas yang terdiri dari Fakultas Ekonomi, Fakultas Tehnik, Fakultas Hukum, Fakultas Pertanian, Fakultas Peternakan, FKIP, Fakultas MIPA, Fakultas Kedokteran, Fakultas FATEPA.

iPhone adalah merek smartphone yang cukup populer di kalangan remaja, baik di kota besar maupun bukan kota besar. Berdasarkan observasi yang peneliti lakukan di Universitas Mataram bahwa keputusan pembelian pada mahasiswa yang menggunakan iPhone untuk melihat karakteristik pribadi, pandangan mereka tentang produk tersebut dan alasan memilih iPhone sebagai produk smartphone yang mereka pilih adalah karena mereka menyukai fitur yang dimiliki dan kecanggihan yang ditawarkan, banyak dipakai oleh teman dan keluarga, trendy, modern dan terkesan mewah serta merasa menjadi pribadi yang lebih modis, berkelas.

Mahasiswa sering mengikuti perkembangan smartphone dikarenakan berbagai macam faktor, termasuk diantaranya untuk bersosialisasi di media sosial dan sebagai kebutuhan dalam mempermudah mencari referensi meteri kuliah, ataupun sebagai hiburan di waktu senggang karena smartphone iPhone memiliki teknologi yang canggih dan efek kamera yang bagus, bahkan sebagai gengsi karena jika memiliki smartphone berteknologi tinggi dan mahal seperti smartphone iPhone akan terlihat selalu tampil up to date dan dapat meningkatkan kepercayaan diri pada saat melakukan berbagai kegiatandiluar.
Dalam penelitian ini, dari sekian banyak variabel yang dapat mempengaruhi keputusan pembelian peneliti hanya memilih 2 variabel yaitu citra merek dan kualitas produk merupakan variabel yang paling relevan yang dimana citra merek dan kualitas produk merupakan salah satu hal utama yang menjadi pertimbangan konsumen dalam memilih produk smartphone.

\section{Metode}

Jenis penelitian yang digunakan dalam penelitian ini adalah penelitian asosiatif. Lokasi penelitian ini di lakukan di Universitas Mataram tepatnya di Jl. Majapahit No.62, Gomong, Kec. Selaparang, Kota Mataram, Nusa Tenggara Barat. Populasi dalam penelitian ini adalah seluruh mahasiswa Universitas Mataram yang menggunakan smartphone iPhone.

Populasi dalam penelitian ini tidak diketahui pasti berapa jumlahnya, sehingga pada penentuan ukuran sampel dari populasi pada penelitian ini dilakukan berdasarkan jumlah sampel minimum diisyaratkan oleh alat analisa yang digunakan. Jumlah sampel tergantung pada jumlah parameter yang diestimasi. Pedomannya adalah 5-10 kali jumlah parameter yang diestimasi. Menurut Ferdinand (2014), jumlah sampel adalah 5-10 dikali jumlah indikator yang dianalisis. Bila indikator dalam penelitian ini berjumlah 13, maka jumlah sampel minimumnya adalah $5 \times 13=91$. Sehingga diperoleh sampel sebanayak 65 responden, tetapi peneliti membulatkan menjadi 100 responden. Penentuan pengambilan jumlah sampel dilakukan melalui teknik non probability sampling dengan metode purposive sampling. Kriteria responden dalam penelitian ini adalah: (1) Berusia minimal 18 tahun. Batas bawah usia ini digunakan karena di usia 18 tahun seseorang dapat dikatakan sudah dewasa dan memiliki identitas diri karena pada usia tersebut dianggap telah bertanggung jawab oleh dirinya sendiri; (2) Telah menggunakan produk iPhone minimal 3 bulan karena kualitas produk dari iPhone memiliki spesifikasi yang sudah sesuai dengan keterangan pada kemasan; dan (3) Memutuskan sendiri produk yang dibeli.

Metode pengumpulan data merupakan cara yang digunakan oleh peneliti untuk mendapatkan data dalam suatu penelitian. Metode pengumpulan data yang digunakan dalam penelitian ini adalah metode survey. Teknik pengumpulan data yang digunaka adalah observasi, angket, dan online survey. Data yang diperoleh berupa data kualitatif dan data kuantitatif dengan sumber data terdari atas data primer dan data ssekunder.

Dalam penelitian ini penulis menggunakan Skala Likert. Peneliti mengelompokkan tanggapan dari 
masing-masing responden terhadap masing- masing indikator variabel penelitian seperti pada Tabel 2 :

Tabel 2. Interval Kelas

\begin{tabular}{lll}
\hline No & Nilai & Mutu \\
\hline 1 & $1.00-1.80$ & Sangat rendah/sangat buruk \\
2 & $1.81-2.60$ & Rendah/buruk \\
3 & $2.61-3.40$ & Netral \\
4 & $3.41-4.20$ & Tinggi/baik \\
5 & $4.21-5.00$ & Sangat tinggi/sangat baik \\
\hline
\end{tabular}

Dalam penelitian ini, model regresi linear berganda digunakan untuk mengetahui pengaruh citra merek dan kualitas produk terhadap keputusan pembelian smartphone merek iPhone. Adapun model regresi linear bergada penelitian ini di tunjukan persamaan berikut ini

$$
Y=a+b 1 X 1+b 2 X 2+e
$$

Dimana :
Y: Keputusan Pembelian
A: Konstanta
b1: Koefisien regresi variabel X1 (citra merek)
b2: Koefisien regresi variabel X2 (kualitas produk)
X1: Citra Merek
X2: Kualitas Produk
e: Error atau variabel penggangu

Uji $\mathrm{t}$ di gunakan untuk mengetahui bagaimana pengaruh dari variabel bebas terhadap variabel terikat secara parsial. Uji statistic t pada dasarnya menunjukan seberapa jauh pengaruh suatu variabel penjelas secara individual dalam menerangkan variabel terikat. Jika nilai pada kolom signifikan $<0,05$ dan thitung $>$ tabel maka Ho ditolak dan Ha diterima. Uji koefisien korelasi persial dihitung dengan persamaan:

$$
t=\frac{\Gamma \mathrm{p} \sqrt{\mathrm{n}-3}}{\sqrt{1-\Gamma_{p}^{2}}}
$$

Keterangan :

$\Gamma \mathrm{p}=$ korelasi parsial yang ditentukan

$\mathrm{N}=$ jumlah sample

$\mathrm{T}=\mathrm{t}$ hitung yang selanjutnya

\section{Hasil dan Pembahasan}

\section{Deskripsi Data Indikator Variabel Citra Merek (X1)}

Setiadi (2003) mengungkapkan bahwa citra terhadap merek berhubungan dengan sikap yang berupa keyakinan dan preferensi terhadap suatu merek. Tanggapan responden terhadap variabel Citra Merek dapat dilihat pada Tabel 3.

Tabel 3. Deskripsi data dan indikator variabel Citra Merek (X1)

\begin{tabular}{lllllllll}
\hline No & Pernyataan & STS & TS & N & S & SS & Rata- rata & Kategori \\
\hline 1. & $\begin{array}{l}\text { Saya telah mengenal merekiPhone sejak lama } \\
\text { iPhone merupakan smartphone yang moderndan } \\
\text { populer }\end{array}$ & 1 & 4 & 11 & 33 & 48 & 4,17 & Tinggi \\
3. & $\begin{array}{l}\text { Merek smartphone iPhone memilikilogo yang unik } \\
\text { dan khas }\end{array}$ & 1 & 2 & 13 & 28 & 56 & 4,36 & $\begin{array}{l}\text { Sangat } \\
\text { Singgi } \\
\text { Tinggi }\end{array}$ \\
Saya merasa smartphone iPhone dapat \\
$\begin{array}{l}\text { meningkatkanpercaya diri terhadap } \\
\text { penggunanya }\end{array}$
\end{tabular}

Berdasarkan Tabel 3, hasil tanggapan responden yang diukur dengan 8 item pernyataan baik skor masing-masing item maupun skor rata-rata keseluruhan dari variabel Citra Merek yang sebesar 4,05 dan termasuk dalam kategori tinggi. Hal tersebut menunjukan bahwa smartphone iPhone memiliki citra merek yang baik dikalangan mahasiswa di Universitas Mataram. Pada pernyataan "iPhone merupakan smartphone yang modern dan populer" memperoleh skor rata-rata tertinggi sebesar 4,41 masuk dalam kategori sangat tinggi dan skor rata-rata terendah masuk dalam kategori netral diperoleh pada pertanyaan "Saya menggunakan smartphone iPhone untuk menunjang penampilan saya" memperoleh skor rata-rata 3,25

\section{Deskripsi Data Indikator KualitasProduk (X2}

Menurut Kotler dan Amstrong, (2012), kualitas produk (product quality) merupakan senjata strategi potensial untuk mengalahkan pesaing. Kemampuan dari kualitas produk untuk menunjukkan berbagai fungsi termasuk di dalamnya ketahanan, handal, 
ketepatan, dan kemudahan dalam penggunan. Produk dapat dilihat pada Tabel 4.

Tanggapan responden terhadap variabel Kualitas

Tabel 4. Deskripsi data dan indikator variabel Kualitas Produk (X2)

\begin{tabular}{|c|c|c|c|c|c|c|c|c|}
\hline No & Pernyataan & STS & TS & $\mathbf{N}$ & $\mathrm{S}$ & SS & Rata- rata & Kategori \\
\hline 1. & iPhone dikemasdengan teknologi yang canggih & 0 & 4 & 18 & 37 & 41 & 4.15 & Tinggi \\
\hline 2. & Kinerja produkiPhone sangat baik & 0 & 3 & 21 & 32 & 44 & 4.17 & Tinggi \\
\hline 3. & $\begin{array}{l}\text { Produk smartphone iPhone memilikitingkat resolusi } \\
\text { warna yang jernih }\end{array}$ & 1 & 2 & 12 & 32 & 53 & 4.34 & $\begin{array}{l}\text { Sangat } \\
\text { Tinggi }\end{array}$ \\
\hline 4. & $\begin{array}{l}\text { Aplikasi iPhonetelah mengikutiperkembangan } \\
\text { jaman }\end{array}$ & 1 & 2 & 7 & 38 & 52 & 4.38 & $\begin{array}{l}\text { Sangat } \\
\text { Tinggi }\end{array}$ \\
\hline 5. & $\begin{array}{l}\text { Smartphone iPhone memilikipenampilan produk yang } \\
\text { inovatif disetiap produknya }\end{array}$ & 0 & 5 & 27 & 45 & 23 & 3.86 & Tinggi \\
\hline 6. & $\begin{array}{l}\text { Smartphone iPhone memilikipenampilan produk } \\
\text { yang inovatif disetiap produknya }\end{array}$ & 1 & 2 & 20 & 40 & 37 & 4.10 & Tinggi \\
\hline 7. & $\begin{array}{l}\text { Setiap tipe iPhone mempunyai fitur- fitur yang } \\
\text { berbeda }\end{array}$ & 0 & 3 & 27 & 44 & 26 & 3.93 & Tinggi \\
\hline 8. & $\begin{array}{l}\text { iPhone memilikifitur yang unik dan berbeda dengan } \\
\text { merek yang lain }\end{array}$ & 1 & 3 & 20 & 38 & 38 & 4.09 & Tinggi \\
\hline 10. & iPhone memilikimodel yang menarik & 1 & 3 & 16 & 43 & 371 & 4.12 & Tinggi \\
\hline 11. & .Desain iPhoneunik dan menarik & 1 & 4 & 19 & 40 & 36 & 4.06 & Tinggi \\
\hline 12. & $\begin{array}{l}\text { Produk smartphone iPhone menawarkan beragam } \\
\text { warnayang menarik }\end{array}$ & 1 & 5 & 12 & 47 & 35 & 4.10 & Tinggi \\
\hline 13. & $\begin{array}{l}\text { iPhone merupakan smartphone yang memiliki } \\
\text { ketahanan yangbaik. }\end{array}$ & 2 & 14 & 34 & 29 & 21 & 3.53 & Tinggi \\
\hline 14. & $\begin{array}{l}\text { iPhone dapat bertahan lama dan dapat digunakan } \\
\text { lebihdari } 2 \text { tahun }\end{array}$ & 0 & 4 & 40 & 31 & 25 & 3.77 & Tinggi \\
\hline 15. & iPhone tidak cepat rusak daneror & 1 & 13 & 41 & 20 & 25 & 3.55 & Tinggi \\
\hline 16. & $\begin{array}{l}\text { Spesifikasi yangdimiliki } i \text { Phone sesuai dengan } \\
\text { keterangan padakemasan }\end{array}$ & 1 & 3 & 14 & 45 & 37 & 4.14 & Tinggi \\
\hline \multirow[t]{2}{*}{17.} & $\begin{array}{l}\text { Saya merasa } i \text { Phone memilikikesesuaian antara } \\
\text { kualitas produk dengan harga }\end{array}$ & 0 & 4 & 20 & 40 & 36 & 4.08 & Tinggi \\
\hline & Rata-Rata & & & & & & 4,01 & Tinggi \\
\hline
\end{tabular}

Berdasarkan Tabel 4 hasil tanggapan responden yang diukur dengan 17 item pernyataan dari 100 responden yang mengisi kuesioner dapat dilihat dari skor masing-masing item maupun skor keseluruhan item dari variabel Kualitas Produk yang sebesar 4,01 dan termasuk dalam kategori tinggi. Hal tersebut menunjukan bahwa smartphone iPhone memiliki Kualitas Produk yang terus berinovasi dalam memproduksi produk-produk smartphone yang berkualitas dan canggih sehingga dapat memenuhi kebutuhan mahasiswa saat ini di Universitas Mataram. Pada pernyataan "Aplikasi iPhone telah mengikuti perkembangan jaman" memperoleh skor rata-rata tertinggi sebesar 4,38 masuk dalam kategori sangat tinggi dan skor rata-rata terendah masuk dalam kategori tinggi diperoleh pada pertanyaan "iPhone merupakan smartphone yang memiliki ketahanan yang baik" memperoleh skor rata-rata 3,53.

\section{Deskripsi Data Indikator Keputusan Pembelian (X3)}

Menurut Kotler \& Amstrong (2014), keputusan pembelian adalah tahap dalam proses pengambilan keputusan pembeli di mana konsumen benar-benar membeli. Tanggapan responden terhadap variabel KeputusanPembelian dapat dilihat Tabel 5.

Tabel 5. Deskripsi data dan indikator variabel Keputusan Pembelian (Y)

\begin{tabular}{|c|c|c|c|c|c|c|c|c|}
\hline No & Pernyataan & STS & TS & $\mathbf{N}$ & $S$ & SS & Rata-rata & Kategori \\
\hline 1. & $\begin{array}{l}\text { Saya memilih untuk membelilphone berdasarkan } \\
\text { keputusan sayapribadi }\end{array}$ & 3 & 4 & 23 & 37 & 33 & 3,93 & Tinggi \\
\hline 2. & $\begin{array}{l}\text { Saya yakin memilih } i \text { Phonesebagai pilihan pertama } \\
\text { ketika memutuskan untuk membeli smartphone }\end{array}$ & 4 & 15 & 27 & 28 & 26 & 3,57 & Tinggi \\
\hline 3. & $\begin{array}{l}\text { Setelah mendapatkaninformasi mengenai smartphone } \\
\text { iPhone saya mengevaluasisecara teliti untuk } \\
\text { mengambil keputusan sebelum membeli }\end{array}$ & 3 & 5 & 17 & 41 & 34 & 3,98 & Tinggi \\
\hline 4. & $\begin{array}{l}\text { Saya membeli iPhone berdasarkan informasi yangsaya } \\
\text { miliki }\end{array}$ & 2 & 4 & 16 & 46 & 32 & 4,02 & Tinggi \\
\hline 5. & Saya mencari informasi tentang smartphone iPhone & 1 & 3 & 21 & 44 & 31 & 4,01 & Tinggi \\
\hline
\end{tabular}




\begin{tabular}{|c|c|c|c|c|c|c|c|c|}
\hline No & Pernyataan & STS & TS & $\mathbf{N}$ & $\mathrm{S}$ & SS & Rata-rata & Kategori \\
\hline & kepadateman yang menggunakan iPhone & & & & & & & \\
\hline 6. & $\begin{array}{l}\text { Saya akan mengumpulkaninformasi sebanyak mungkin } \\
\text { sebelum membeli smartphone iPhone }\end{array}$ & 1 & 4 & 13 & 44 & 38 & 4,14 & Tinggi \\
\hline 7. & $\begin{array}{l}\text { Saya lebih memilih iPhonedibanding smartphone merek } \\
\text { lain. }\end{array}$ & 5 & 8 & 32 & 30 & 25 & 3,62 & Tinggi \\
\hline 8. & $\begin{array}{l}\text { Saya memiliki keyakinan untukmembeli smartphone } \\
\text { iPhone dibandingkan smartphone lain }\end{array}$ & 3 & 9 & 32 & 32 & 24 & 3,65 & Tinggi \\
\hline 9. & $\begin{array}{l}\text { Saya membandingkansmartphone } i \text { Phone dengan } \\
\text { smartphone lainuntuk mengambil keputusan }\end{array}$ & 2 & 5 & 21 & 41 & 31 & 3,94 & Tinggi \\
\hline 10. & $\begin{array}{l}\text { Setiap kali menggunakan } i \text { Phone saya memiliki keinginan } \\
\text { untuk membeli } i \text { Phone dengan tipe yanglebih tinggi dan } \\
\text { aplikasi yang lebih lengkap }\end{array}$ & 3 & 5 & 28 & 35 & 29 & 3,82 & Tinggi \\
\hline 11. & $\begin{array}{l}\text { Saya memiliki keinginan untukmembeli } i \text { Phonedengan } \\
\text { model dan desain yangbaru }\end{array}$ & 3 & 6 & 19 & 46 & 26 & 3,86 & Tinggi \\
\hline \multirow[t]{2}{*}{12.} & $\begin{array}{l}\text { Saya ingin membeli lagi smartphone iPhone karena harga } \\
\text { yang ditawarkan sesuai dengan kemampuan saya }\end{array}$ & 5 & 7 & 28 & 40 & 20 & 3,63 & Tinggi \\
\hline & Rata-rata & & & & & & 3,84 & Tinggi \\
\hline
\end{tabular}

Berdasarkan Tabel 5, hasil tanggapan responden yang diukur dengan 12 item pernyataan baik skor masing-masing item maupun skor rata-rata keseluruhan dari variabel Keputusan Pembelian yang sebesar 3,84 dan termasuk dalam kategori tinggi. Pada pernyataan "akan mengumpulkan informasi sebanyak mungkin sebelum membeli smartphone iPhone" memperoleh skor rata-rata tertinggi sebesar 4,14 masuk dalam kategori tinggi dan skor rata-rata terendah diperoleh pada pertanyaan "yakin memilih iPhone sebagai pilihan pertama ketika memutuskan untuk membeli smartphone" memperoleh skor rata-rata 3,57 masuk dalam kategori tinggi. Hal ini menunjukan bahwa mahasiswa di Universitas Mataram akan mengumpulkan informasi sebanyak mungkin dalam keputusan pembelian smartphone iPhone.

\section{Analisis Regresi}

Analisis regresi berganda digunakan untuk meramalkan suatu keadaan variabel dependen (kriterium), bila dua atau lebih variabel independen sebagai faktor prediktor dimanipulasi (dinaik turunkan nilainya) (Sugiyono, 2006).

Tabel 6. Uji Regresi Linier Berganda

\begin{tabular}{llll}
\hline Model & \multicolumn{2}{l}{$\begin{array}{l}\text { Unstandardized } \\
\text { Coefficients }\end{array}$} & $\begin{array}{l}\text { Standardized } \\
\text { Coefficients }\end{array}$ \\
\cline { 2 - 4 } & B & Std. Error & Beta \\
\hline (Constant) & 3.050 & 3.715 & \\
Total_X1 & .564 & .177 & .358 \\
Total_X2 & .363 & .092 & .447 \\
\hline
\end{tabular}

Dari Table 46 diperoleh persamaan regresi:

$$
\mathrm{Y}=3,050+0,564+0,363+\mathrm{e}
$$

Persamaan tersebut meinterpretasikan bahwa: (1) Nilai konstan sebesar 3,050 dengan parameter positif, menunjukkan bahwa apabila nilai variabel citra merek dan kualitas produk dianggap nol, maka nilai keputusan pembelian akan sebesar 3,050; (2) Koefisien regresi variabel citra merek sebesar 0,564 dengan parameter positif, hal ini berarti setiap perubahan pada variabel citra merek (X1) sebesar satu satuan akan mengakibatkan perubahan keputusan pembelian sebesar 0,564. Sebaliknya penurunan satu satuan pada variabel citra merek akan menurunkan keputusan pembelian sebesar 0,564 dengan asumsi- asumsi lain adalah tetap; (3) Koefisien regresi variabel kemudahan sebesar 0,363 dengan parameter positif, hal ini berarti setiap perubahan pada variabel kualitas produk (X2) sebesar satu satuan akan mengakibatkan perubahan keputusan pembelian sebesar 0,363. Sebaliknya penurunan satu satuan pada variabel kualitas produk akan menurunkan keputusan pembelian sebesar 0,363 dengan asumsi-asumsi lain adalah tetap.

\section{Uji Hipotesis \\ Uji Parsial (Uji-t)}

Uji $t$ di gunakan untuk mengetahui bagaimana pengaruh dari variabel bebas terhadap variabel terikat secara parsial. Uji statistic t pada dasarnya menunjukan seberapa jauh pengaruh suatu variabel penjelas secara individual dalam menerangkan variabel terikat. Jika nilai pada kolom signifikan $<0,05$ dan thitung $>t_{\text {tabel }}$ maka Ho ditolak dan Ha diterima

Tabel 7. Hasil Uji T

\begin{tabular}{llllll}
\hline \multirow{2}{*}{ Model } & \multicolumn{6}{l}{ Coefficients } & \\
\cline { 2 - 6 } & B & \multicolumn{2}{l}{ Std. Error Beta } & T & Sig. \\
\hline (Constant) & 3.050 & 3.715 & & .821 & .414 \\
Total_X1 & .564 & .177 & .358 & 3.177 & .002 \\
Total_X2 & .363 & .092 & .447 & 3.964 & .000 \\
\hline
\end{tabular}

Berdasarkan Tabel 7 dapat dilihat bahwa: (1) Nilai t hitung pada variabel citra merek sebesar 3,177 dan nilai signifikansi sebesar 0,002 . Nilai thitung lebih besar dibandingkan table $(3,177>1,660)$ dan nilai signifikansi lebih kecil dari $0,05 \quad(0,002<0,05)$. Berdasarkan hasil tersebut maka Ho ditolak dan Ha diterima yang artinya citra merek secara parsial 
mempunyai pengaruh yang signifikan terhadap keputusan pembelian; (2) Nilai thitung pada variabel kualitas produk sebesar 3,964 dengan signifikansi sebesar 0,000 . Nilai thitung lebih besar dibandingkan table $(3,964>1,660)$ dan nilai signifikansi lebih kecil dari 0,05 $(0,000<0,05)$. Berdasarkan hasil tersebut maka Ho ditolak dan Ha diterima yang artinya kualitas produk secara parsial mempunyai pengaruh yang signifikan terhadap keputusan Pembelian.

\section{Uji Koefisien Detereminasi (R2)}

Koefisien Determinasi digunakan untuk menggambarkan kemampuan model menjelaskan variasi yang terjadi dalam variabel dependen. Nilai $R^{2}$ adalah antara nol dan satu. Jika $\mathrm{R}^{2}$ mendekati satu, berarti kontribusi atau sumbangan variabel $X$ terhadap Y semakin besar dan apabila $\mathrm{R}^{2}$ mendekati nol berarti kontribusi variabel $\mathrm{X}$ terhadap $\mathrm{Y}$ kecil. Hasil analisis koefisien determinasi (R2) ditunjukkan pada Tabel 8.

Tabel 8. Hasil Koefisien Detereminasi (R2)

\begin{tabular}{|c|c|c|c|}
\hline Model R & R Square & $\begin{array}{l}\text { Adjusted R } \\
\text { Square }\end{array}$ & $\begin{array}{l}\text { Std. Error of } \\
\text { the Estimate }\end{array}$ \\
\hline .768 & .589 & .581 & 5.708 \\
\hline
\end{tabular}

Berdasarkan hasil perhitungan koefisien regresi dalam penelitian ini diperoleh nilai Adjusted R Square sebesar 0,581. Hal ini berarti variabel independen dapat menjelaskan variasi dari variabel dependen sebesar 58,1\%. Sedangkan sisanya sebesar $41,9 \%$ dijelaskan olehvariabel lain di luar variabel penelitian.

\section{Pembahasan}

Penelitian ini bertujuan untuk mengetahui pengaruh citra merek (X1) dan kualitas produk (X2) terhadap keputusan pembelian (Y) smartphone iPhone pada mahasiswa di Universitas Mataram. Hasil penelitian ini yang telah diuraikan baik dengan menggunakan alat analisis asosiatif, selanjutnya dikaitkan dengan teori-teori yang menjadi landasan teori, hasil penelitian terdahulu, dan fakta atau kondisi di lapangan.

Berdasarkan hasil uji parsial (Uji-t) diperoleh nilai t hitung sebesar 3,177 dan nilai signifikansi lebih kecil dari $0,05(0,002<0,05)$, dan koefisien regresi 0,564 ; maka penelitian ini berhasil membuktikan hipotesis pertama yang menyatakan bahwa "Citra Merek memiliki pengaruh positif dan signifikan terhadap keputusan pembelian".

Citra merek merupakan hal yang menjadi pertimbangan penting seseorang ketika akan membeli smartphone iphone karena iPhone merupakan smartphone yang sangat populer di dunia dan terkenal dengan kecanggihan dan harganya yang mahal, sehingga para pengguna atau user iPhone terutama dikalangan mahasiswa yang sebagian besar menyukai sesuatu yang populer dikalangannya akan merasa bergengsi dan lebih percaya diri ketika menggunakan iphone. Citra merek adalah bagaimana suatu merek mempengaruhi persepsi, pandangan masyarakat atau konsumen terhadap perusahaan atau produknya (Dewi et al., 2015). Citra merek merupakan suatu gambaran atau kesan tentang suatu merek yang muncul dalam benak konsumen. Penempatan suatu merek dalam benak konsumen harus dilakukan secara terusmenerus agar citra merek yang tercipta menjadi semakin positif bagi konsumen. Saat suatu merek mempunyai suatu citra yang positif maka merek tersebut akan semakin diingat oleh konsumen dan akan mempengaruhi pembelian konsumen (Dharma \& Sukaatmadja, 2015). Variabel citra merek dalam penelitian ini memiliki pengaruh positif dan signifikan terhadap keputusan pembelian, Hal tersebut menunjukkan bahwa semakin positif citra merek yang dimiliki suatu produk maka akan semakin meningkatkan keputusan pembelian.

Berdasarkan hasil uji parsial (Uji- $t$ ) diperoleh nilai $\mathrm{t}$ hitung sebesar 3,964 dan nilai signifikansi lebih kecil dari $0,05(0,000<0,05)$, dan koefisien regresi 0,363; maka penelitian ini berhasil membuktikan hipotesis kedua yang menyatakan bahwa "Kualitas Produk memiliki pengaruh positif dan signifikan terhadap keputusan pembelian". Kualitas produk juga merupakan hal yang menjadi pertimbangan penting seseorang dalam memilih smartphone iphone. Selain memiliki citra merek yang positif iPhone juga terkenal dengan kualitas produknya yang bagus. iPhone memiliki kualitas produk yang berbeda dengan kebanyakan smartphone baik dari fitur, spesifikasi maupun daya tahannya.

Dengan kecanggihan teknologinya tersebut smartphone iPhone digunakan oleh kalangan mahasiswa untuk menunjang kegiatan mereka. Menurut Kotler dan Armstrong (2012), kualitas produk adalah kemampuan sebuah produk dalam memperagakan fungsinya, hal ini termasuk keseluruhan durabilitas, reliabilitas, ketepatan, kemudahan pengoperasian, dan reparasi produk, juga atribut produk lainnya.Kualitas produk merupakan hal penting yang harus diusahakan oleh setiap perusahaan apabila menginginkan produk yang dihasilkan dapat bersaing di pasar. Adanya hubungan timbal balik antara perusahaan dengan konsumen akan memberikan peluang untuk mengetahui dan memahami apa yang menjadi kebutuhan dan harapan yang ada pada persepsi konsumen. Maka, perusahaan penyedia produk dapat memberikan kinerja yang baik untuk mencapai kepuasan konsumen melalui cara memaksimalkan pengalaman yang menyenangkan dan meminimalisir pengalaman yang kurang menyenangkan konsumen 
dalam menggunakan produk. Variabel kualitas produk dalam penelitian ini memiliki penaruh positif dan signifikan terhadap keputusan pembelian, yang artinya semakin tinggi kualitas produk maka akan semakin meningkatkan keputusan pembelian.

\section{Kesimpulan}

Berdasarkan hasil penelitian dan pembahasan maka dapat disimpulkan bahwa: (1) Citra merek berpengaruh positif dan signifikan terhadap keputusan pembelian smartphone iphone pada mahasiswa di Universitas Mataram. Artinya semakin baik citra merek yang dimiliki maka semakin tinggi keputusan pembelian smartphone iPhone pada mahasiswa di Universitas Mataram. Penelitian ini menunjukan hipotesis diterima; (2) Kualitas produk berpengaruh positif dan signifikan terhadap keputusan pembelian smartphone iphone pada mahasiswa di Universitas Mataram. Artinya semakin baik kualitas produk yang dimiliki maka semakin tinggi keputusan pembelian smartphone iPhone pada mahasiswa di Universitas Mataram. Penelitian ini menunjukan hipotesis diterima; (3) Dari hasil uji kelayakan model (uji F) menunjukan bahwa variable citra merek dan kualitas produk berpengaruh positif dan signifikan terhadap keputusan pembelian smartphone iPhone pada mahasiswa di Universitas Mataram. Artinya semakin baik citra merek dan kualitas produk maka semakin tinggi keputusan pembelian smartphone iPhone pada mahasiswa di Universitas Mataram. Penelitian ini menunjukan hipotesis diterima.

\section{Referensi}

Amalia, N., Moita, S., \& Tawulo, M. A. (2018). Dampak Penggunaan Tekhologi Handphone Terhadap Pola Interaksi Suami dan Isteri. New Societal, 3(2), 400-407.

Daeng, I. T. M., Mewengkang, N. ., \& Kalesaran, E. R. (2017). Penggunaan Smartphone Dalam Menunjang Aktivitas Perkuliahan Oleh Mahasiswa Fispol Unsrat Manado Oleh. E-Journal "Acta Diurna," 6(1), 1-15.

Dewi, D. R., Magdalena, M., \& Dhiana, P. (2015). Pengaruh Word of Mouth, Tingkat Pendapatan dan Kualitas Produk terhadap Keputusan Pembelian yang Berdampak Pada Minat Beli Ulang Konsumen (Studi Kasus pada Produk Bandeng Juwana Elrina Semarang). Journal of Management, 1(1), 1-19. http://jurnal.unpand.ac.id/index.php/MS/articl e/viewFile/254/250

Dharma, N. P. S. A., \& Sukaatmadja, I. P. G. (2015). Pengaruh Citra Merek, Kesadaran Merek, Dan
Kualitas Produk Terhadap Keputusan Membeli Produk Apple. E-Jurnal Manajemen Unud, 4(10), 3228-3255.

Hartati, A. S., Hurriyati, R., \& Widjajanta, B. (2017). Gaya Hidup Konsumen Dalam Pengambilan Keputusan Pembelian. Journal of Business Management Education (JBME), 2(1), 57-64. https://doi.org/10.17509/jbme.v2i1.5981

Kasmawati, K. (2018). Sumber Daya Manusia Sebagai Sumber Keunggulan Kompetitif. Idaarah: Jurnal Manajemen Pendidikan, 2(2), 229. https://doi.org/10.24252/idaarah.v2i2.6864

Kotler, \& Armstrong. (2012). Pemasaran Produk dan Merek (Planning \& Strategy). CV. Penerbit Qiara Media.

Maharani, N. (2015). Proses Pengambilan Keputusan Pembelian Konsumen Terhadap Produk Iphone Di Bandung. Jurnal Manajemen Dan Bisnis (Performa), 12(1), 59-75. https://elearning2.unisba.ac.id/index.php/perfo rma/article/view/3043

Oktavenia, K. A. R., \& Ardani, I. G. A. K. S. (2018). Pengaruh Kualitas Produk Terhadap Keputusan Pembelian Handphone Nokia Dengan Citra Merek Sebagai Pemediasi. E-Jurnal Manajemen Universitas Udayana, 8(3), 1374. https://doi.org/10.24843/ejmunud.2019.v08.i03.p 08

Permana, Slamet, M., \& Oktavian Haryanto, J. (2014). Pengaruh Country Of Origin, Brand Image Dan Persepsi Kualitas Terhadap Intensi Pembelian. Jurnal Manajemen, XVIII(03), 365-380.

Sugiyono. (2006). Statistika untuk Penelitian. Alfabeta. 